Fisunenko P. A., Ph.D. in Economics, Associate Professor Prydniprovska State Academy of Civil Engineering and Architecture

Dnipro, Ukraine

DOI: https://doi.org/10.30525/978-9934-26-018-6-16

\title{
ECONOMIC SECURITY OF CONSTRUCTION ENTERPRISES: METHODOLOGICAL BASIS FOR EVALUATION
}

The process of ensuring the economic security of the construction enterprises involves the evaluation of its security level.

Many scientists devoted their works to the problem of evaluation of economic security, including N. Atramonova, A. Atrashkova, A. Arbatov, I. Binko, O. Bazhenova, I. Bilyk, T. Vasyltsiv, V. Varenyk, O. Denisov, S. Dovbnya, N. Gichova, I. Gubenko O. Ivanilov, N. Ivanchenko, S. Kavun, A. Korableva, V. Karpov, M. Kopytko, O. Kutukova, N. Mukhitov, O. Podmazko, V. Martynenko, O. Saenko, E. Terekhov, B. Udovich, S. Ustenko, V. Chernova, O. Chernyak, V. Shlemko, Y. Kharazishvili, I. Yaremko and others. As research has shown, only a few scientists pay attention to the sectoral specifics of the economic security of the enterprise (especially for construction enterprises).

At the legislative level, the assessment of economic security of enterprises is not approved, but two documents contain basic ensurement for this issue, namely: in the Methodical recommendations for identifying signs of insolvency of the enterprise and signs of actions to conceal bankruptcy, fictitious bankruptcy or 
bankruptcy, approved by the Order of the Ministry of Economy № 1361 (v1361665-10) dated 26.10.2010 [4] and Methodical recommendations for forecasting the consequences and assessing the impact of privatization of certain categories of enterprises on the state of economic security of the government, approved by the Order of the Ministry of Economy № 518 dated 29.05.2009 [5].

Systematization of existing scientific works of researchers in the field of assessing the level of economic security of enterprises allowed to identify the lack of coherence of opinions and positions of scientists who studied these issues. The main drawbacks of the existing methodological base of the evaluation of economic security of the enterprises are:

1) the approaches to evaluation developed by scientists are based on forming a certain hierarchy of criteria, indicators or indices;

2) there is a difference in the structuring of economic security into certain components;

3) the same component may carry a different content load on economic security, which is reflected in the use of different list of indicators for evaluation;

4) some approaches may contain different evaluation criteria;

5) there is a difference in the interpretation of the level of economic security both in the intervals and in their number, which leads either to complication or to simplistic interpretation.

Regarding the first disadvantage, the following variations have been identified:

- selection of evaluation indicators without specifying criteria, indicators or indices;

- selection of evaluation indicators without specification of criteria or detalization by indicators (in this case the indicators are equated to indices);

- selection only the evaluation criteria, which in this case can be equated to indicators;

- selection of evaluation criteria, which are met by certain indicators or indices represented by a set. 
After analysing the approaches to the assessment of economic security, suggested in various sources, it should be noted that researchers often identify separate criteria and separate indicators in different interpretations (Table 1).

Table 1

Systematization of scientists according to their positions on the assessment of economic security of the enterprise

\begin{tabular}{|l|c|c|c|}
\hline \multicolumn{1}{|c|}{ Authors } & $\begin{array}{c}\text { Availability } \\
\text { of } \\
\text { evaluation } \\
\text { criteria }\end{array}$ & $\begin{array}{c}\text { Availability } \\
\text { of } \\
\text { evaluation } \\
\text { indicators }\end{array}$ & $\begin{array}{c}\text { Availability } \\
\text { of } \\
\text { evaluation } \\
\text { indices }\end{array}$ \\
\hline $\begin{array}{l}\text { S. Dovbnya, N. Gichova, } \\
\text { O. Ivanilov, S. Ustenko, } \\
\text { N. Ivanchenko, I. Bilyk, } \\
\text { S. Kavun }\end{array}$ & & + & + \\
\hline $\begin{array}{l}\text { N. Atramonova, } \\
\text { A. Atrashkova, } \\
\text { R. Skrynkovky }\end{array}$ & & + & \\
\hline $\begin{array}{l}\text { N. Mukhitov, A. Arbatov, } \\
\text { O. Podmazko, } \\
\text { V. Martynenko, V. Geets, } \\
\text { M. Kyzym, T. Klebanova, } \\
\text { O. Chernyak }\end{array}$ & + & & \\
\hline $\begin{array}{l}\text { B. Koretsky, } \\
\text { A. Sukhorokuva, } \\
\text { Y. Kharazishvili, } \\
\text { E. Terekhov, V. Vakhlakova }\end{array}$ & & & + \\
\hline M. Kopitko, V. Chernova & + & & + \\
\hline $\begin{array}{l}\text { O. Kutukova, B. Udovich, } \\
\text { O. Saenko }\end{array}$ & + & & + \\
\hline $\begin{array}{l}\text { I. Yaremko, V. Varenyk, } \\
\text { O. Denisov }\end{array}$ & + & + & + \\
\hline
\end{tabular}

Conducting a critical analysis of existing scientific papers on the separation of components of economic security (the second drawback) revealed that: 
- there is either too small (which does not disclose the necessary aspects of economic security) or too large (which overloads or duplicates the assessment) list of components;

- there are different names of components of economic security, which have one meaning.

After analysing the approaches to the separation of components of economic security of the enterprise in the process of its evaluation, that have been revealed in various theories, it should be noted that researchers often use from four to eight of its components. The vast majority of scientists suggest to separate financial, informational, personnel, power, ecological, technological, legal and political functional components in the composition of economic security.

It can be concluded, that for construction companies it is impractical to single out the political and legal component, as for companies in a single sector, its content and significance will be the same. Also, it is not entirely appropriate to refer to the functional components of economic security the legal and force one. Providing enterprises with these types of security, which reflects protection against raiding, is a function of state bodies and services that operate on the basis of approved relevant laws and regulations and form the appropriate institutional environment for the protection of enterprises.

Therefore, it can be suggested to include financial, information, personnel, environmental and technological components in the list of economic security assessment of construction enterprises. The practical support for the development of a methodological approach to evaluating the level of economic security should be based on quantitative and qualitative indicators, integrated into a system with the ability to change their weight without changing the methodology itself.

On this basis, an approach to evaluating the economic security of a construction enterprise is suggested, which includes the following stages:

1. Substantiation of the criteria for assessing the economic security of the construction company.

2. Structuring economic security by components.

3. Determining the values of indicators and their rationing. 
4. Determination of weights coefficients (components of economic security of the construction enterprise and indicators within the components of economic security).

5. Calculation of the integrated indicator of economic security.

6. Interpretation of the integrated indicator of economic security and determination of its level.

7. Diagnosis of the nature of the construction enterprise.

The suggested methodological approach will allow to conduct a comprehensive evaluation of the level of economic security of the construction company in the context of its ensurement, taking into account industry characteristics.

\section{References:}

1.Dovbnia S.B., Hichova N.Yu. (2008) Diahnostyka rivnia ekonomichnoi bezpeky pidpryiemstva [Diagnosis of the level of economic security of the enterprise]. Finansy Ukrainy, no. 4, pp. 88-97.

2.Ivanilov O.S., Dmytriieva O.I. (2018) Metody otsinky rivnia ekonomichnoi bezpeky promyslovykh pidpryiemstv [Methods for assessing the level of economic security of industrial enterprises]. Problemy i perspektyvy rozvytku pidpryiemnytstva, no. 2 , pp. 66-83.

3.Kopytko M.I. (2015) Kompleksne zabezpechennia ekonomichnoi bezpeky pidpryiemstva (na materialakh pidpryiemstv transportnoho mashynobuduvannia) [Complex maintenance of economic safety of the enterprise (on materials of the enterprises of transport engineering)] ( $\mathrm{PhD}$ thesis), Kyiv: VNZ «Universytet ekonomiky i prava «KROK».

4.Metodychni rekomendatsii shchodo vyiavlennia oznak neplatospromozhnosti pidpryiemstva ta oznak dii z prykhovuvannia bankrutstva, fiktyvnoho bankrutstva chy dovedennia do bankrutstva : zatv. nakazom M-va ekonomiky Ukrainy vid 26.10.2010 № 1361. URL: https://zakon.rada.gov.ua/rada/show/v0014665-06\#Text (accessed 15 December 2020).

5.Metodychni rekomendaciji shhodo proghnozuvannja naslidkiv ta ocinky vplyvu na stan ekonomichnoji bezpeky derzhavy pryvatyzaciji dejakykh kateghorij pidpryjemstv: zatv. nakazom M-va ekonomiky Ukrajiny vid 29.05.2009 № 518. URL: https://me.gov.ua/Documents/Detail?lang=uk-UA\&id=5caa4594-1080-434a-aa14 aef920293b0b\&title=MetodichniRekomendatsiiSchodoPrognozuvanniaNaslidkivTaO tsinkiVplivuNaStanEkonomichnoiBezpekiDerzhaviPrivatizatsiiDeiakikhKategoriiPid priiemstv (accessed 15 December 2020).

6.Ghejecj V.M., Kyzym M.O., Klebanova T.S. (2006) Modeljuvannja ekonomichnoji bezpeky: derzhava, reghion, pidpryjemstvo [Modeling of economic security: state, region, enterprise]. Kharkiv: VD «INZhEK». (in Ukrainian)

7.Ponomarenko V.S., Kavun S.V. (2008) Konceptualjni osnovy ekonomichnoji bezpeky [Conceptual foundations of economic security]. Kharkiv: Vydavnyctvo KhNEU. (in Ukrainian) 